\title{
SHOULD NEW ZEALAND SHIRK ITS OBLIGATIONS? A CRITICAL PERSPECTIVE ON PRIVATE LAW SCHOLARSHIP
}

\author{
Bevan Marten* and Geoff McLay**
}

\begin{abstract}
This article concerns the role of the private law scholar in New Zealand, and how such scholars use their skills to improve the law. It argues that while an obligations scholar's preference may be to engage with the courts and other academics in their scholarly activities, a focus on statutory reform better suits New Zealand conditions. Scholars should share their talents with policy makers, law reform bodies and legislators, helping to explain the importance of a coherent system of private law, and how this may be achieved. The authors then go a step further by suggesting that, in the New Zealand context, the preferable approach to reform may be one involving policy-based solutions exemplified by the accident compensation scheme, as opposed to approaches based on traditional private law principles such as party autonomy.
\end{abstract}

\section{A QUESTION OF PRIORITIES}

This article asks how, as New Zealand private law scholars, we can improve the law of this relatively small common law jurisdiction. It revolves around two related themes: first, New Zealand conditions suggest the prioritisation of reform based on legislation; and secondly, private law scholars in New Zealand should engage with the policy-making and legislative process. Having settled on such a topic in the context of a collection of articles dedicated to New Zealand private law, we have deliberately set out to be challenging. However, we wish to stress that this piece has been written with genuine respect for the intellectual ability and dedication displayed by those who research and write in this field. We believe that private law scholars have invaluable perspectives that should not be lost to the important business of New Zealand law-making, but that being involved in that process requires private law scholars to move out of their comfort zone. Our hope is

* Senior Lecturer, School of Law, Victoria University of Wellington.

** Professor, School of Law, Victoria University of Wellington. Geoff served as a New Zealand Law Commissioner from 2010 to 2015. 
that this brief contribution sparks a response from our private law colleagues, and that through this dialogue we may all reflect more deeply on our academic role.

\section{II "WORLD CLASS" IN NEW ZEALAND}

In developing this piece we acknowledge our debt to Hector MacQueen's (Professor of Law at Edinburgh University and a Scottish Law Commissioner) 2013 Willi Steiner Memorial Lecture "Invincible or Just a Flesh Wound? The Holy Grail of Scots Law". MacQueen points out the difficulties facing a jurisdiction of just over five million people, relying on often old or isolated firstinstance case law for guidance, but with courts facing a steady decline in civil business, a dominant neighbouring jurisdiction, and a litigation model that favours high-value cases over legally significant ones. ${ }^{1}$ MacQueen suggests that it is necessary for Scotland to reflect on how it goes about reforming its law: ${ }^{2}$

One specific lesson which I draw from all these observations is the need, not just to reform the law, but also to think hard about the need for doing it by way of legislation or even codification. The difficulty of saying what Scots law is in many areas of current concern has borne itself in upon me repeatedly in writing national notes for Scotland for European private law publications and even more urgently in making contributions to joint projects with the Law Commission of England \& Wales. Far too often one is left making extrapolations from nineteenth-century or earlier cases or drawing upon isolated (and not infrequently unreported) single judge decisions of more recent provenance. If the relatively time-rich professor or Law Commissioner finds such exercises problematic, what of the hard-pressed practitioner advising clients? The difficulties can be exacerbated by the writers of legal textbooks and treatises taking widely divergent views of such authorities as exist in the sources. A code - or quasi-codifying statutes in particular area - would at least have the merit of stating authoritatively what the law is, for good or ill. And if it turned out to be ill, it could then be reformed with better understanding of what the problems for solution are. That is a solution not readily available in a Common Law system.

MacQueen ended his lecture by imploring his listeners not to try to defend the status quo of Scots law, but to respond as well as they could to the "economic, political and social facts of our civilisation and make our law fit for consideration as part of the common law of the world". 3

While New Zealand does not have to contend with multiple parliaments and superior courts in the way that Scotland must, MacQueen's concerns may nonetheless be echoed in this country. As law students in core courses on property, contract and torts repeatedly discover, many aspects of New Zealand private law still rely heavily on 18th and 19th century English precedent. Although it

1 Hector MacQueen "The 4th Willi Steiner Memorial Lecture: Invincible or Just a Flesh Wound? The Holy Grail of Scots Law" (2014) 14 LIM 2.

2 At 10.

3 At 11. 
is difficult to separate out those cases touching substantively on private law subjects, it seems uncontroversial to state that New Zealand's courts are given relatively few opportunities to reassess and update these common law authorities. For example, in 2013 there were 296 civil appeals filed in the New Zealand Court of Appeal compared with 1,142 appeals filed and 4,291 applications "filed or set down" in the Court of Appeal of England and Wales. ${ }^{4}$ In the most recent statistics available, the civil jurisdiction of the New Zealand Court of Appeal saw an 18 per cent decline in the number of new appeals filed compared with the previous year: from 296 appeals (2013-2014) to 242 (20142015). ${ }^{5}$ Given that many of these will be of a public or regulatory law nature, the numbers of cases touching substantively on private law doctrines will be low indeed.

Our purpose here is not to suggest that New Zealand should encourage more civil litigation, or otherwise to engage with the civil law "justice gap" highlighted by the Chief High Court Judge in late 2014. ${ }^{6}$ The point raised here is that a common law system relying on case law to develop its private law doctrines, especially to meet changing social circumstances, needs judges to have before them a staple of fertile material. The Lord Chief Justice of England recently suggested that even that jurisdiction's courts were undersupplied with precedent-making cases. ${ }^{7}$ Private law is too complex, and its scope too wide, to be sustained by the efforts of the New Zealand courts alone.

The familiar answer to this challenge is of course to look abroad; to locate New Zealand's law within the common law family and import those developments that this country has not yeen able to consider. While we would never dream of rejecting this approach outright, we do wish to raise a few increasingly evident difficulties. First, the necessity of doing so makes the law inaccessible to the ordinary citizen. Secondly, there are plenty of examples to support the argument that England, Australia, Canada and the other common law jurisdictions that New Zealand has traditionally looked to for inspiration and guidance are moving increasingly further apart. The "Europeanisation" of private law has had a significant impact on the United Kingdom, ${ }^{8}$ and any

4 "Annual Statistics for the Court of Appeal June 2014" Courts of New Zealand <www.courtsofnz.govt.nz>; and Ministry of Justice (UK) Court Statistics Quarterly January to March 2014: Ministry of Justice Statistics bulletin (June 2014) at 37.

5 "Annual Statistics for the Court of Appeal June 2015" Courts of New Zealand <www.courtsofnz.govt.nz>.

6 Helen Winkelmann "The New Zealand Law Foundation Ethel Benjamin Commemorative Address 2014: Access to Justice - Who Needs Lawyers?" (2014) 13 Otago LR 229.

7 Lord Thomas of Cwmgiedd, Lord Chief Justice of England and Wales "Developing commercial law through the courts: rebalancing the relationship between the courts and arbitration" (The Bailii Lecture 2016, 9 March 2016).

8 See for example in the contract law context Gerhard Dannemann and Stefan Vogenauer "Introduction: The European Contract Law Initiative and the 'CFR in Context' Project" in Gerhard Dannemann and Stefan Vogenauer (eds) The Common European Sales Law in Context: Interactions with English and German Law (Oxford University Press, Oxford, 2013) 1. 
New Zealand scholar of conflicts of laws has felt this particularly keenly. ${ }^{9}$ Both Australia and England have reformed their rules on pre-contractual non-disclosure in insurance law, leaving New Zealand to apply the original common law tests. ${ }^{10}$ Even accepting that many areas of common ground remain, such a list could stretch across many pages.

As a result, New Zealand needs to consider, in many situations, the advantages of legislative reform over the traditional common law approach to legal development. Others may disagree, and press for an approach that promotes a coherent (and internationally applicable) law of obligations. ${ }^{11}$ In either case, a preliminary point is that we should not shirk from a consideration of New Zealand needs. Not just because our paycheques are largely drawn from the public purse, but because research touching on New Zealand law can be of international significance.

One threat to this kind of endeavour comes in the form of research assessment exercises that seem to celebrate the global over the domestic by making the term "international" a byword for quality. New Zealand's Performance-Based Research Fund (PBRF) does this by classing an academic as "Quality Category B" if they have produced publications of "a high quality" and "acquired recognition by peers for their research at least at a national level", whereas a "Quality Category A" academic will have publications of a "world class standard" and have "made a significant contribution to the New Zealand and/or international research environments". ${ }^{12}$ Although the guidelines are not so blunt as to state that articles in international journals are better than those in domestic ones, or that one could not be deserving of "Quality Category A" status with a purely New Zealand-based reputation, the implication is clear to working academics: publish often and publish offshore. MacQueen similarly observed that there was a sense the United Kingdom government's Research Excellence Framework evaluations have turned scholars away from the examination of Scots law, on the basis that it might seem parochial and not "world class". ${ }^{13}$ We are a little heartened by recent efforts to broaden the assessment criteria to include impacts on policy. ${ }^{14}$

9 See Andrew Dickinson "What, if Anything, can Australia Learn from the EU Experience?" in Andrew Dickinson, Mary Keyes and Thomas John (eds) Australian Private International Law for the 21 st Century: Facing Outwards (Hart, Oxford, 2014) 157 at 158-161. Dickinson's comments are equally applicable to New Zealand.

10 Insurance Contracts Act 1984 (Cth); Consumer Insurance (Disclosure and Representations) Act 2012 (UK); Insurance Act 2015 (UK); and Jaggar v QBE Insurance International Ltd [2007] 2 NZLR 336 (CA).

11 See Part III below.

12 "Quality Category A" and "Quality Category B" as defined in Tertiary Education Commission Performance-Based Research Fund: Guidelines for the 2018 Quality Evaluation assessment process (Wellington, 2016) at 32.

13 MacQueen, above n 1, at 5.

14 See references to policy impacts in connection with "Research Outputs" and "Research Contributions" in Performance-Based Research Fund: Guidelines, above n 12, at 46-47 and 56-58. 
Academics' research agendas are of course not purely driven by the six-yearly PBRF cycle, but for the ambitious, the pressure to publish internationally is ever-present: "The more senior the level of promotion, the more important is publication in international journals and books ... relative to other forms of scholarly publication." 15 With this kind of incentive, private law scholars are well placed to focus their efforts on concerns of a more global nature, operating from New Zealand without necessarily engaging in its legal landscape. While accepting that this is an option that appeals to some, who would argue the international focus of their careers has made them more relevant and engaged than they would otherwise be, we urge our colleagues to turn, from time to time, to their own backyard for inspiration.

Private law research focusing on New Zealand issues, whether published in New Zealand or elsewhere, can be of "world interest" as well as being "world class". The problems confronting this small jurisdiction, and our attempts to resolve those problems (whether through statutory reform or case law), are of interest to the outside world, especially when placed in the wider international context. In fact the ability to compare and contextualise is one that makes the academic role particularly valuable - to show domestic readers where local developments fit within the global scheme and to show international readers how a particular jurisdiction is reacting to the challenges in question.

\section{GLOBAL OBLIGATIONS}

If the pressure to develop an international portfolio is one factor pushing New Zealand's private law scholars away from local engagement, another is the move across the common law world to the study of the law of obligations.

As we perceive it, the model of the law of obligations that currently dominates international discussion presents private law as an autonomous body, quasi-philosophical in nature that is to be evaluated by virtue of coherence and internal consistency. This body of law exists (or should grow to exist) within the common law, but usually discussion revolves around an abstract common law, removed from any particular jurisdiction. Obligations scholars are working to perfect this body of law, drawing on concepts such as party autonomy and private ordering, innate notions of justice between private parties and logic.

Let us take as an example Professor Charles Rickett's article in this volume where he argues that to allow the trustee of an express trust to impose by their conduct a beneficial interest in the same trust property, leading the court to recognise a constructive trust: ${ }^{16}$

15 Victoria University of Wellington Academic Staff Collective Agreement - Term: 1 July 2014-30 June 2016 at 31 under the heading of "Promotion Criteria". A copy is available at <www.teu.ac.nz>.

16 Charles Rickett "Instrumentalism in the Law of Trusts: The Disturbing Case of the Constructive Trust upon an Express Trust" (2016) 47 VUWLR 463 at 474-475. 
... is not only instrumentalist and therefore doctrinally incoherent, but it is in fact in itself to sanction unjustness. The only interest the trustee can yield is an interest in property belonging to others. That is to create a liability in others who may well not be in any way responsible and at the same time to steal from some to give to another. It is Robin Hood law. It is the kind of law that exists in some parts of the world, like Zimbabwe, but it must not be allowed to creep into New Zealand, no matter how appealing the instrumental reasoning that accompanies it might at face value seem. The rule of law is not only a signal theme of public law but private law enhances it and is reliant on it. The rule of law is a system of justice. It takes rights seriously. When courts start to ignore rights and rule on the basis of intuitions of fairness and unconscionability and so on, we move away from justice to regulation.

Rickett's argument is that the answer to the problem the courts are trying to address, that of how to deal with trust property in the wake of relationship breakdowns, could be solved by the common law on unjust enrichment with the assistance of private law scholars. By contrast, if the courts continue to take the current approach of using trust law to deal with the problem, they will destabilise the common law on trusts. ${ }^{17}$

His article ends by engaging with the theme of our own: ${ }^{18}$

Alternatively, of course, we might want to despair of that possibility and hand the matter over to law reform bodies and the Parliament for statutory resolution. It seems that might indeed be a possible panacea in New Zealand for the relationship property problem. But whatever we do, creating a shambles in the well thought out and case hardened law of trusts is not an outcome we should relish. Indeed, it is a prospect that private lawyers in particular should be critically and conscientiously concerned about. For soon, if the rot continues, we will have nothing to say because there will be nothing to talk about.

Rickett's comments neatly encapsulate the strengths of the obligations model and what it has to offer. The ability to take a broad view of private law, analyse perceived attacks on its doctrinal coherence, and suggest better avenues for the problems at hand - all within the scope of the common law. Furthermore the justifications for those doctrines are not blindly supported by reference to precedent, but by reference to philosophical justifications about how private law and society should interact. But what we suggest is that, rather than handing over such matters in despair to law reform agencies or Parliament, it ought to be our role not only to actively engage with these institutions' projects, but also to help set their agenda. In this way we can make them the more likely agents than the courts to deal with the problems that changed circumstances present for the law. Law reform is not what we do when we give up thinking, it is rather the point of thinking in the first place.

17 At 475 .

18 At 476 


\section{IMPROVING NEW ZEALAND'S PRIVATE LAW}

We do not suggest for a moment that there is no value in the kind of scholarship exemplified by Rickett and other prominent academics. Instead our hope is that New Zealand's private law scholars will take the time to share their skills with New Zealand's policy makers and legislature to help improve this jurisdiction's law; to follow research articles through with suggestions for reform, engage in the consultation process when policy or legislative projects are underway, and not to rely solely on the accretion of case law.

In general terms, we argue that statutory reform is the better means of private law reform. The law becomes more accessible, is given the imprimatur of Parliament (which is best placed to decide on any policy issues that arise), and enables a broad view of a problem to be taken as opposed to the haphazard and piecemeal nature of common law developments. We accept that an obligations scholar might object and suggest that private law is best left alone - that it can fulfil its social role and develop without the meddling of politicians. However, we are sceptical of suggestions that the common law of obligations, left to its own devices and informed by scholarly debate, leads to the best outcomes for those whom the law is supposed to serve.

One major advantage of the legislative approach to reform in the New Zealand context is that the question of what the law is has a clear starting point. In areas not covered by legislation, such as the tort of negligence, New Zealand lawyers must keep an eye on developments in England and elsewhere, and then attempt to guide their clients by surmising the probable approach of a New Zealand court if confronted with a similar issue. Will the New Zealand courts follow the foreign judgment's line of reasoning? What if there is a conflict between the law of Australia and England, for example, and both approaches have their merits? This links back to MacQueen's concerns about the difficulties of a legal system relying on case law, but producing so few civil cases (especially ones that progress to final judgments on legal points). For example, it was a long five year wait for New Zealand between the decision in Henderson v Merret Syndicates and the confirmation of New Zealand's position on concurrent actions in contract and tort in Turton v Kerslake. ${ }^{19}$

New Zealand's building liability cases, starting with Invercargill City Council v Hamlin in $1994,{ }^{20}$ paint a similar picture. Did New Zealand really start out on a different conception of how such cases are to be resolved or simply apply the law to "New Zealand facts"? It has taken several Supreme Court decisions in recent years to clarify the position in the wake of the leaky building crisis. $^{21}$

19 Henderson v Merrett Syndicates [1995] 2 AC 145 (HL); and $R$ M Turton \& Co Ltd (in liq) v Kerslake and Partners [2000] 3 NZLR 406 (CA).

20 Invercargill City Council v Hamlin [1994] 3 NZLR 513 (CA).

21 See for example North Shore City Council v Body Corporate 188529 [2010] NZSC 158, [2011] 2 NZLR 289 [Sunset Terraces]; North Shore City Council v Attorney-General [2012] NZSC 49, [2012] 3 NZLR 341 
Sometimes a statute might be a better means of resolving an issue than analysing the issue from a private law perspective. Take an example from the world of credit repossession, where a practice developed for a power of attorney or agency clause to sometimes be added to a credit contract. The repossession agency might then use this power to add additional goods to the list, taking more than had apparently been agreed to (this was despite possible private law obligations that doing so might have been a breach of the purpose for which the power was given). ${ }^{22}$ This practice was abolished by statute in 2014. ${ }^{23}$ The public policy interest of consumer protection was necessary to overrule the private ordering between two parties with a significant power imbalance.

The kind of undertaking we are describing here can be achieved without sacrificing the principled commitment of the obligations scholar to doctrinal coherence and the common law method. Taking the trust example referred to above, the government (whether in the guise of the Law Commission, a ministry or Parliament itself) should be told how the courts have gotten it wrong to date and, crucially, why this is a problem from a private law perspective and how it can be resolved. Private law scholars are uniquely placed to do this and there is no sense in sitting on the side lines if a reform project is underway that touches on a private law scholar's area of interest, only to later criticise the outcome in a learned article.

We now outline two caveats in relation to this preferred approach. First, successfully engaging with legislative reform is difficult. Secondly, the type of reform that New Zealand needs will, in our view, often depart from an obligations scholar's notion of a good legal solution.

\section{A We Need to be Better at Arguing for Change, or the Status Quo}

While we would argue that the statutory route is the better one, legislative reform in areas covered by obligations scholars will often struggle to gain public policy traction in the responsible government departments or political traction with Ministers.

This creates challenges for private law scholars in New Zealand. It is important that we articulate - much better than is currently done - why consistent and coherent private law is important to New Zealand as matter of public policy. In our view, a very good claim can be made that a modern and efficient private law is a key part of a country's legal infrastructure. That might seem self-evident to academics in this field, but it is not always self-evident for those used to evaluating proposals by reference to evidence-based policy protocols. Those responsible for this process might struggle with generalised philosophical claims that law reform is unnecessary because

[The Grange]; and Body Corporate No 207624 v North Shore City Council [2012] NZSC 83, [2013] 2 NZLR 297 [Spencer on Byron].

22 Law Commission Consumers and Repossession: A Review of the Credit (Repossession) Act 1997 (NZLC $\mathrm{R} 124,2012)$ at 33 .

23 Credit Contracts and Consumer Finance Amendment Act 2014, s 51. 
it would create injustice between two hypothetical contracting parties, for example, when they have been asked to address what has been framed as a social problem confronting thousands of individuals.

Private law scholars should therefore be prepared to learn how the policy-making process works and engage with it, as opposed to waiting for submissions to select committees, when the core issues and the chosen approach have already been established. After all, government policy-making processes are becoming more accessible, with exposure drafts of bills and public submissions called for during the policy creation stage more frequently. Rather than seeing such engagement as a distasteful watering-down of the scholarly mission, this ability to exercise the skills of modern, practical reform should be celebrated - and successful engagements rewarded professionally. And surely it is more satisfying to look back and say "I was partly responsible for that statute", than to say "I wrote an article criticising that statute the week after it was passed"?

But what if a scholar decides that statutory reform is unlikely to pass the basic thresholds required by evidence-based policy, or senses that the matter will never make it on to the legislative agenda? This is clearly the case in some areas of private law (reform of maritime liens seems distinctly unlikely in the near future, ${ }^{24}$ for example), and we do not suggest that statutory reform is a global panacea. However, in such cases, we should be more reluctant to end articles with the conclusion that although a particular case is unjust it cannot be changed except by Parliament. Instead we should urge the New Zealand courts to bite the bullet and accept that they should get on with the reform process itself as best they can. This was ultimately the experience in New Zealand in relation to Parliament's repeated failure to reform the limitation regime before the final passage of the Limitation Act 2010, for example. In such situations private law scholars can assist the judiciary by making clear the case for reform and the options available, and providing support for what the judge might then try to do with the common law resources available.

\section{B Different Models of Legislative Reform}

If a private law scholar accepts that legislative reform is necessary to correct a problem in New Zealand's private law, they may be thinking of a reform through which Parliament uses a short statute to nudge the common law back on track. New Zealand's statute book features a series of contract law statutes (notably Frustrated, Illegal, Mistakes, Remedies and Privity) ${ }^{25}$ through which the uncertainties of the common law have been circumvented by legislative clarifications, fix-ups and workarounds. These examples might not have been enacted in pursuit of public policy goals that differ significantly from the priorities of contract law scholars generally, but they do demonstrate the power of legislation to take the confusion out of a problem created by the common law process.

24 Fournierv The ship "Margaret Z" [1999] 3 NZLR $111(\mathrm{HC})$ at 119.

25 Frustrated Contracts Act 1944; Illegal Contracts Act 1970; Contractual Mistakes Act 1977; Contractual Remedies Act 1979; and Contracts (Privity) Act 1982. 
By and large they have been a success, even if the theoretical baggage with which they were passed has been disputed. ${ }^{26}$ Similar comments could be made in relation to the various tort law reform statutes. Indeed, these are now such a familiar part of the established legal firmament that it is often forgotten that the survival of tort claims after death, comparative (as opposed to contributory) negligence, and contribution amongst joint tortfeasors are all the creatures of statute rather than common law. ${ }^{27}$

To this extent, we hope to have taken most private law scholars with us, at least as far as accepting that statutory reform can have a legitimate role in private law reform, and that the skills of academic lawyers can be put to good use when such statutes are being cooked up. Where we are likely to part company with a number of them is in proposing that, for New Zealand conditions, the best approach to reform will often lean heavily on public policy concerns, and at times depart radically from the common law. With this approach the private/public divide in law falls away to a large extent, as lawmakers search for pragmatic solutions to problems based on policy goals such as the protection of consumers or the facilitation of commerce. Core obligations-type concepts such as fairness between parties or the predictability of results can be bargained away (sometimes unintentionally) in this process, or considered from different perspectives.

The classic example of this approach is the Woodhouse Report (50 years old next December) that led to New Zealand's accident compensation scheme. ${ }^{28}$ The right to sue was removed and the policy goal of a common response to personal injury by accident was inserted in its place. Issues like party autonomy, corrective justice or the restoration of private relations that dominate the way that obligations scholars often now speak of tort $\operatorname{law}^{29}$ were not as dominant in the scholarship then, but if they had been they would probably have been seen as somewhat beside the point. The point was that the common law simply could not, and indeed cannot, provide the kinds of compensation and rehabilitation that social policy demands as the response to accidents.

Another example with a wide scope of application is the Personal Property Securities Act 1999 (PPSA), in relation to which New Zealand emulated North American initiatives that have since

26 See for instance the debate between Professors McLauchlan and Sutton over the degree to which the Contractual Mistakes Act 1977 was intended to remake the fundamental nature of what amounts to an agreement: DW McLauchlan "More on the Contractual Mistakes 'Code"' (2003) 9 NZBLQ 51; and Richard Sutton "The Code of Contractual Mistake: What Went Wrong?" (2003) 9 NZBLQ 234.

27 Law Reform Act 1936; Law Reform Act 1944; Contributory Negligence Act 1947; Death By Accidents Compensation Act 1952; Domestic Actions Act 1975; and Defamation Act 1992.

28 AO Woodhouse, HL Bockett and GA Parsons Compensation for Personal Injury in New Zealand: Report of the Royal Commission of Inquiry (December 1967).

29 See for instance the work of Ernest J Weinrib The Idea of Private Law (revised ed, Oxford University Press, Oxford, 2012); or Allan Beever Rediscovering the Law of Negligence (Hart, Oxford, 2007). 
spread to Australia. ${ }^{30}$ This model promotes the provision of credit terms to businesses by introducing a simplified ranking of priorities based on straightforward statutory criteria combined with a register of interests. In exchange, the common law concept of title to goods is pushed aside. The New Zealand case of Graham v Portacom New Zealand Ltd, in addition to being the first reported decision on the Act's provisions, provides a stark example of its operation. ${ }^{31}$ Portable cabins were loaned to a company that ran into financial troubles. The registration provisions of the PPSA were not complied with. The failing company's creditors moved in and, under the PPSA, had a higher-ranked claim to the cabins than Portacom as the cabins' owners. The private ordering between Portacom and the failed company, and the individual injustice of a company having its property seized to satisfy the debts of another, were subsidiary to the interests of a clear system that can quickly be learned and applied by non-lawyers throughout the business world.

Finally, and accepting that it will never be as famous as Sir Owen's triumph of law reform, the humble Carriage of Goods Act 1979 affects the majority of New Zealanders each week, especially in this age of online shopping. By creating a codified liability regime and limiting virtually all claims for loss or damage during domestic carriage to $\$ 2,000,{ }^{32}$ the Act's success can be measured in the lack of amendments it has undergone in the years since its introduction, ${ }^{33}$ despite the wide range of industries it serves. The age-old difficulties of determining fault in the transport context are stripped away - along with older common law concepts such as the common carrier ${ }^{34}$ - in exchange for a simplified strict liability system. ${ }^{35}$

There are also pieces of legislation that engage less directly with the common law, but instead introduce a new angle of approach that bypasses its complexities. For instance, the Fair Trading Act 1986 takes the concept of "misleading or deceptive conduct in trade" and expands on it to proscribe a variety of undesirable practices. ${ }^{36} \mathrm{~A}$ variety of remedies is available, including orders to pay damages, refund money or return property, vary contracts, supply goods and so on. ${ }^{37}$ The Act is a common sight in New Zealand pleadings, and extends to disputes between commercial parties. ${ }^{38}$

30 Roger Fenton Garrow \& Fenton's Law of Personal Property in New Zealand (7th ed, LexisNexis, Wellington, 2010) vol 2 at ch 2; and Personal Property Securities Act 2009 (Cth).

31 Graham v Portacom New Zealand Ltd [2004] 2 NZLR 528 (HC).

32 Carriage of Goods Act 1979, s 15.

33 Ports of Auckland Ltd v Southpac Trucks Ltd [2009] NZSC 112, [2010] 1 NZLR 363 at [1].

34 Carriage of Goods Act 1979, s 28.

35 Ports of Auckland Ltd, above n 33, at [2]-[4].

36 Fair Trading Act 1986, s 9.

37 Section 43.

38 A Westlaw NZ case search for references to the legislation since its enactment returns close to 5,800 hits. 
Faced with its broad notions of fairness and its flexible collection of remedies, why would a legal advisor not suggest adding it to the list of causes of action, rather than tangling with potentially complex common law actions and remedies? The relatively short Act cuts through a wide range of complexities on the strength of the policy of promoting fairness in trade. But the Act is also an example of an area that could do with much more attention from private law scholars, who might be better equipped than others in properly exploring what coherence and consistency in the law might mean for the metes and bounds of the Act. A similar comment could be made for impact of the Resource Management Act 1991 (and local government law in general) on the law of nuisance and other land-related aspects of tort law. ${ }^{39}$

\section{PRIVATE LAW SCHOLARS HAVE MUCH TO OFFER}

The public policy-driven model of statutory reform could be seen as a threat to the dominant model of obligations scholarship. Clearly reforms like ACC deliberately advance the policy goal chosen over the values of autonomy or coherence that private law scholars might favour. Public policy will sometimes seem to cheerfully mix criminal and public law concepts into its legal formulae if these are seen as the most appropriate mechanisms, and the means of reform will almost inevitably involve messy legislative compromise. For example, a large bank might be prepared to forgo justice in individual cases in exchange for a law that is easy to comply with when applied to thousands of customers, preferring to use electronic systems and a high degree of automation to save resources overall. Similarly two insurance companies might prefer to take a "knock for knock" approach to settling claims, rather than trying to determine the extent to which each company's insured driver was actually liable for a car accident.

But we think that this sense of threat is misplaced, and simply rejecting what the public policy wonks want to do as impure is a waste of much of the private law scholar's learning and insights. In fact the very values, insights and skills that private law scholars bring to their work are often those that are most needed in the turning of policy objectives into effective, quality legislation. The private law scholar might fear that their insights and skills would be wasted at this level of detail, and more suited to abstract theoretical discussions about the law that might later filter down into legislative change. However, if private law scholars fail to engage with this process, or do not engage in a way that those running the process will understand, then they miss the opportunity to shape the outcomes of those reforms. At the very least, we are not convinced that writing for common law practitioners and judges alone will be as effective a means of reform as writing for policymakers and legislators. We think this is true even when the public policy goal might contradict the conclusions that a private law scholar might draw as the solution to a particular problem. It is our belief that autonomy and coherence remain important objectives of the way in which policy reforms are enacted. We are both fans of the broad Woodhouse approach but we also

39 See for example Antoinette Besier "Leaving it all to the Resource Management Act 1991: The Demise of the Private Tort of Nuisance" (2004) 35 VUWLR 563. 
both believe that the way in which that vision is enacted could greatly benefit from more rigour, and from the insight of the common law into some of the more difficult problems that it needs to solve. ${ }^{40}$

Returning to the themes discussed in connection with MacQueen's article above, it seems that New Zealand is failing to engage in significant areas of common law development; most notably the law of restitution and the role of unjust enrichment that has proceeded apace in the English courts since the early 1990s, ${ }^{41}$ but which (with some notable exceptions) has passed most New Zealand lawyers by. The notion of developing a cohesive common law approach to restitution within the current New Zealand framework will be very difficult, if not impossible, to achieve. By contrast, a Law Commission inquiry followed by statutory reform might not provide a perfect solution to every problem, but it would at least provide a timely starting place. Private law scholars should be convincing government and policymakers to make this kind of project a priority.

Alternatively, by turning to the question of how legislative reform might improve New Zealand's private law, scholars in this country could engage in areas that have been sadly neglected of late, such as the accident compensation regime. Academic lawyers can bring value to discussions of fairness under the Fair Trading Act, on the importance of private ordering in the context of contract law reform and on the role of personal responsibility in the context of a "no fault" scheme of compensation.

\section{CONCLUSION: BEING A SUCCESSFUL NEW ZEALAND PRIVATE LAW ACADEMIC}

What does success look like for a New Zealand private law scholar? A DPhil at Oxford, a presentation at Obligations IX and an article in the Law Quarterly Review? All of these are wonderful achievements, but some contribution to New Zealand law must surely also be rewarding. And while any private law scholar can identify areas for improvement in the law, the challenge in our view is to make one's analysis count in New Zealand - to achieve reform, or to educate those who make the decisions about reform that private law counts too. We would be the last to suggest that the kinds of deep thinking, and writing, that questions the direction of the law, or interrogates those who seek to change it or to use it for their own purposes is not valuable; indeed it is essential. But what we would argue is that as scholars we should also be concerned about insisting on our relevance in the law-making process.

In this article we have argued that to make itself relevant, private law scholarship needs to be translated into the "real world" of 21 st century New Zealand law. We all write for different

40 See for example Geoff McLay "Accident Compensation - What's the Common Law Got to Do With It?" [2008] NZ L Rev 55; and Bevan Marten "ACC's Cover Provisions Need a Makeover" [2016] NZLJ 223.

41 See generally Graham Virgo The Principles of the Law of Restitution (3rd ed, Oxford University Press, Oxford, 2015). 
audiences at different times, and sometimes a theoretical piece is precisely what is needed, as for example during the early stages of an emerging common law doctrine. ${ }^{42}$ But from time to time we should lift our eyes from the pages of black letter law and see what others are doing outside of the academic sphere. This is not a zero-sum game; one does not have to decide between the Law Quarterly Review and providing value to New Zealand law. We can, and should, be trying to do both. The policy and legislative process may conjure up images of Bismarck and sausages, but New Zealand conditions dictate that it is the most effective means of change.

42 See for example Nicole Moreham "A Conceptual Framework for the New Zealand Tort of Intrusion" (2016) 47 VUWLR 283 